\title{
obituary
}

\section{James Fleming McHarg}

Formerly Consultant

Psychiatrist, Royal Dundee

Liff Hospital and Honorary

Senior Lecturer at Dundee

University

James McHarg V.R.D. died on 10 March

2003, in his 86th year.

He graduated in Medicine at Edinburgh University in 1940 and then served in the Royal Navy, first on an Atlantic convoy destroyer and then as senior medical officer to a submarine base, achieving the rank of surgeon-commander.

In civilian life, his professional career was spent in three Scottish Royal Psychiatric Hospitals; the Royal Edinburgh, Gartnavel Royal (Glasgow) and Royal Dundee Liff. In Edinburgh, he was strongly influenced by Sir David Henderson and also by Professor Jan Rostowski - an impressive refugee Polish professor of neurology. From these years, he developed a lasting interest in neuropsychiatric syndromes. However, he was not a narrow specialist. On the contrary - he was an avowed general psychiatrist, and indeed sceptical of the formal specialisation that has marked the development of psychiatry in recent decades.

From Edinburgh, he moved to Gartnavel as Deputy Physician Superintendent. He was awarded his MD with commendation in 1959 for a thesis on Schilder's disease (diffuse sclerosis). He published on childhood mania, an important contribution to

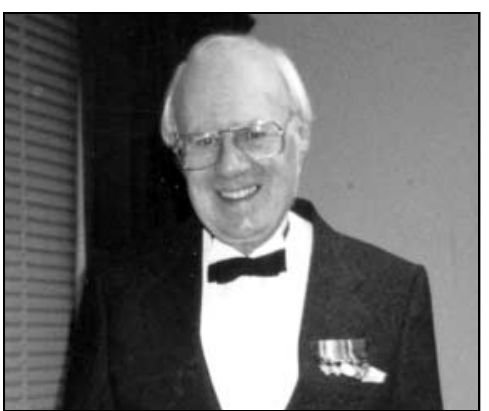

the literature on affective psychosis in children, and began to collect cases of torsion dystonia, a condition not infrequently misdiagnosed, in his view, as hysteria, and he became a valuable adviser to the Dystonia Society. He was highly regarded by his colleagues as a clinician and as a stimulating adviser to junior staff.

After Glasgow, he moved to Dundee as Consultant and Honorary Senior Lecturer in the Department of Psychiatry of Dundee University, until his retirement in 1981. By then he had been elected a Fellow of the Royal College of Physicians of Edinburgh in 1958 and, in 1971, a Foundation Fellow of the Royal College of Psychiatrists in 1971. His interest in the latter led him to found the McHarg Essay Prize, awarded to a trainee psychiatrist who had produced an outstanding research paper.

In his latter working years, James encountered patients who reported 'paranormal' experiences and he explored this material with characteristic tenacity and rigour. He became a member of the
Society for Psychical Research and corresponded widely with fellow members, abroad as well as in the UK. As recently as last year, he presented a well-received paper on 'Poltergeists' to the Senior Fellows of the Royal College of Physicians of Edinburgh.

Mention must now be made of James McHarg as an historian. In researching his family tree he encountered ancient forgotten documents which he realised were of relevance to the early history of the College of Physicians of Edinburgh. There followed years of painstaking research, crowned in 1997 by the publication of his book In Search of Dr. John MakLuire: Pioneer Edinburgh Physician, forgotten for over three hundred years. His researches were, however, not exclusively into medical history. For example, just this year, he published a successful identification of a 17th century warship shown in an obscure painting in Aberdeen Maritime Museum. It was proved to be, in fact, the flagship of the pre-Union Scots Navy.

James was a devout man, widely read in theology, theological history and philosophy; his participation in the life and councils of the Scottish Episcopalian Church was one of the key influences in his life and was widely appreciated. He will be remembered as a quietly humorous and kindly man, a generous and loyal friend and a compassionate doctor. He did not marry, but was a devoted uncle to his nephew and three nieces, the four children of his deceased sister.

\section{Peter Aungle}

\section{forthcoming events}

\footnotetext{
The 7th Annual Maxwell Jones

Lecture will be held on Friday, 12 September 2003 at 7.45 p.m. at the Royal Institute of British Architects in central London. The lecture will be given by $\mathrm{Dr}$ Mark Morris, Consultant Psychiatrist in Psychotherapy at the Portman Clinic. Dr Gill McGauley, Consultant and Senior Lecturer in Forensic Psychotherapy at St George's Hospital Medical School, will give the response. The title of the lecture will be 'Therapeutic communities behind bars; treatment and consent'. For further details, please contact Henderson Hospital, 2 Homeland Drive, Sutton, Surrey SM5 4ES (tel: 0208661 1611).

Continuing professional development Meetings on the Internet. The Royal College of Psychiatrists, in association with the Royal College of Physicians of London, will be holding live interactive
}

continuing professional development meetings on the Internet at 8 p.m. on Thursday, 18 September 2003 (Alzheimer's disease) and on Wednesday, 22 October (depression). Participants will be able to see the speakers, view the synchronised slides and submit questions electronically. An archive of the proceed ings will be available afterwards. These meetings are part of a new educational series titled RCPlive, launched by the Royal College of Physicians in April 2003. Further details of the programme and speakers, together with free online registration are available by logging on to the website http://www.rcplive.ac.uk Early registration is advised.

The 20th Annual Meeting of the Society for Psychotherapy Research (SPR) UK will be held in Ravenscar, North Yorkshire, on 21-24 March 2004. The deadline for submission of papers is 10 October 2003. Papers or posters are welcome from all psychiatrists, psychologists and mental health practitioners involved in psychotherapy research. For abstract forms and further information, please visit the SPR website at http:// www.spr.org.uk or contact Debra KirbyMayers, SPR Administrator, 1 Ansley Grove, Heaton Moor, Stockport SK4 3LF (tel/fax: 0161432 4507).

The World Psychiatric Association, in collaboration with the Italian Psychiatric Association, would like to announce the international congress, Treatments in Psychiatry: an update. The congress will be held in Florence, Italy on 10-13 November 2004. The deadline for submission of abstracts is 30 September 2003. For further details please visit http://www.wpa2004florence.org 